Vol. XXIII No 12017

\title{
COMMANDER'S MANAGERIAL COMPETENCES IN THE CZECH ARMED FORCES
}

\author{
Pavla MACHÁČKOVÁ, Jiř́ HODNÝ, Jan ZEZULA \\ University of Defence, Brno, The Czech Republic \\ pavla.machackova@unob.cz
}

\begin{abstract}
The paper summarizes the research results of commanders' managerial competences. The aim of the research consisted in identifying facts, which managerial competences make or do not make troubles for commanders; there are offered recommendations for the development of commanders' critical competences. The research was conducted within three groups of respondents: the first group comprised senior officers, participants of the General Staff course; the second group comprised junior officers, participants of the senior officer course, and the third group covered graduates of the basic officers' course. Using the questionnaire research, respondents rated ten selected managerial competences of their subordinates. The research results concluded that commanders face the greatest difficulties in communication, self-development and analytical thinking.
\end{abstract}

\section{Keywords: commander, competences, quantitative research, Czech Armed Forces}

\section{Introduction}

The fundamental concepts such as manager, leader and competence have become widely discussed even in the military environment in the Czech Armed Forces. There can be found countless models of aptitudes and skills required for effective leading subordinates; however, research on detecting its quality appear in the Czech Armed Forces environment just sporadically. The aim of this paper consists in drawing attention to far little researched survey covering the level of commanders' managerial competences in the Czech Armed Forces and acquainting readers with the main results of empirical research, which had been conducted by the authors of the paper.

\section{Specification of commander's key competences}

To perform the empirical research of commanders' managerial competences level, first, the key managerial competences as well as their content had to be defined and specified. Creating the initial model of commander's key competences consisted in searching selected studies and publications in order to find, or, possibly define a simple operationalized model of managerial competencies, which would enable creating a simple tool for measuring, or respectively evaluating commander's competencies.

When determining competences, the publication Leadership by Horana (in Vrchota) [1] is based on research resulting from self-evaluation of managers, i.e., which competences are the most significant for the executing managerial activities: those are efficiency, responsibility, purposefulness, knowledge, decisiveness, creativity, ability to compromise, perseverance, collaboration, and communication.

In 2003, the Kienbaum Consultants International organization presented results 
of its research [2], which had been carried out at the management of word leading companies: its aim was to identify the most important skills, which should be mastered by their managers. Those specified competences were sorted by relevance as follows: motivation, targeting, team-work ability, communication, ability to work under pressure, analytical skills, willingness to learn, lead, flexibility, decisiveness (10 competences by relevance had been selected).

The U.S. Army Leadership Field Manual [3] defines the commander's competence model as a set of values (loyalty, responsibility, respect, unselfishness, honesty, scrupulousness, courage), attributes (mental, physical, emotional), knowledge and skills (communication, decisiveness, creativity, couching, mentoring, knowledge, monitoring).

The National system of Occupations of the Czech Republic [4] defines the following soft skills for a senior executive: communication, collaboration, creativity, flexibility, efficiency, independence, problem-solving, life-long learning, activity, coping with workload, leadership.

"The Decree on the procedure for official evaluation for soldiers and its considerations" of 2015 [5] is a further document, which had been considered for creating a core group of commander's competencies; there are ten evaluation criteria as follows: fulfilment of duties, qualification, efficiency, responsibility, communication, reliability, independence, analytical skills, coping with workload, interpersonal relationships.

Vrchota [6] defines key managerial competencies for the enterprise management as follows: communication, collaboration, ability to solve problems (make decisions), ability to learn, independence, efficiency orientation, creativity, responsibility, ability to think, and ability to evaluate. The model advantage consists in offering empirically measurable indicators as well.
Novák's [7] structured competence model of ten managerial competencies is a very similar typology with predetermined indicators; the authors have used it as a starting model for further research covering commander's competencies for successful leadership of teams; it comes to decisiveness, responsibility, goal orientation, efficiency orientation, selfdevelopment, policy, empathy, selfconfidence, communication, creativity. This model was prioritized because of relevant indicators applicable in evaluating commander's key competencies.

The model had been judged professionally by several selected commanders serving in formations of tactical and operational levels, and resulting from that the model was partially modified. The original competence "policy" was replaced by "analytical skills" as this competence reflects better the aspect of military experience. Components (indicators, criteria) of individual competencies were modified in compliance with activities of a military unit commander. The number of competencies appeared to be well suited for creating a research tool, a structured questionnaire dealing with assessing commander's competencies. The questionnaire frame comprised predetermined and defined competencies as follows:

- decisiveness,

- responsibility,

- goal orientation,

- efficiency orientation,

- self-development,

- analytical skills;

- empathy;

- self-confidence,

- communication,

- creativity.

The above presented competencies were always assigned five indicator components characterizing that particular competence. 


\section{Questionnaire survey}

The research goal consisted in identifying those competencies that cause commanders major and minor problems. Questionable competencies and skills bringing commanders troubles are going to be paid attention to in the future by the authors as well in terms of developing commanders' competencies.

Having applied the operacionalized model of commander's managerial competencies, the authors developed a questionnaire consisting of fifty statements. Each statement was assigned a five-point rating scale in compliance with the Czech school grading scale. The questionnaire was distributed among three groups of respondents, i.e., life-long learning participants at the University of Defence: General Staff course, senior officers' course, and basic officers' course graduates. In total, there were 90 respondents (three groups of thirty people). The interviewed persons covered the entire management levels, i.e., from strategic, through operational up to tactical. The data were being collected within $12-16$ December 2016. The questionnaires were returned by $100 \%$.

\section{Main research results}

Researchers tried to answer two research questions.

1. Which competencies at the subordinate commanders are considered questionable by respondents, and which are not?

2. Which skills being a part of individual competencies at the subordinate commanders are classified questionable by respondents, and which are not? Respondents had to assess 50 skills within ten competencies.

Respondents were assessing the level of key competencies of subordinate commanders within the interval 2.09-2.49; according to the Czech school grading scale, the rating ranges between very good up to good (ECTS: B-C). The empirical research showed that respondents perceived at their subordinates competencies such as communication, self-development and analytical thinking ability as the most questionable ones. On the contrary, competencies such as efficiency orientation, goal orientation and decisiveness belonged among the top rated, see graph no. 1 .

No significant differences were found at assessing three most questionable and three top competencies among individual groups of respondents (General Staff course GSC; Senior Officers' course - SOC; Basic Officers' course-BOC), see table no. 1 .

More detailed results, i.e., which skills (indicators) at subordinates within individual competencies are evaluated favourably, and which are considered rather questionable, are presented in the table no. 2 and 3 below.

The table no. 2 shows that skills within competencies goal orientation, efficiency orientation and decisiveness are top rated.

The table no. 3 shows that when assessing subordinate commanders, respondents considered as rather questionable skills within competences communication, empathy, and self-development.

\section{Developing commander's competencies}

The empirical research results show that competencies such as communication, selfdevelopment and analytical thinking ability have the greatest potential for developing commanders' competencies. 


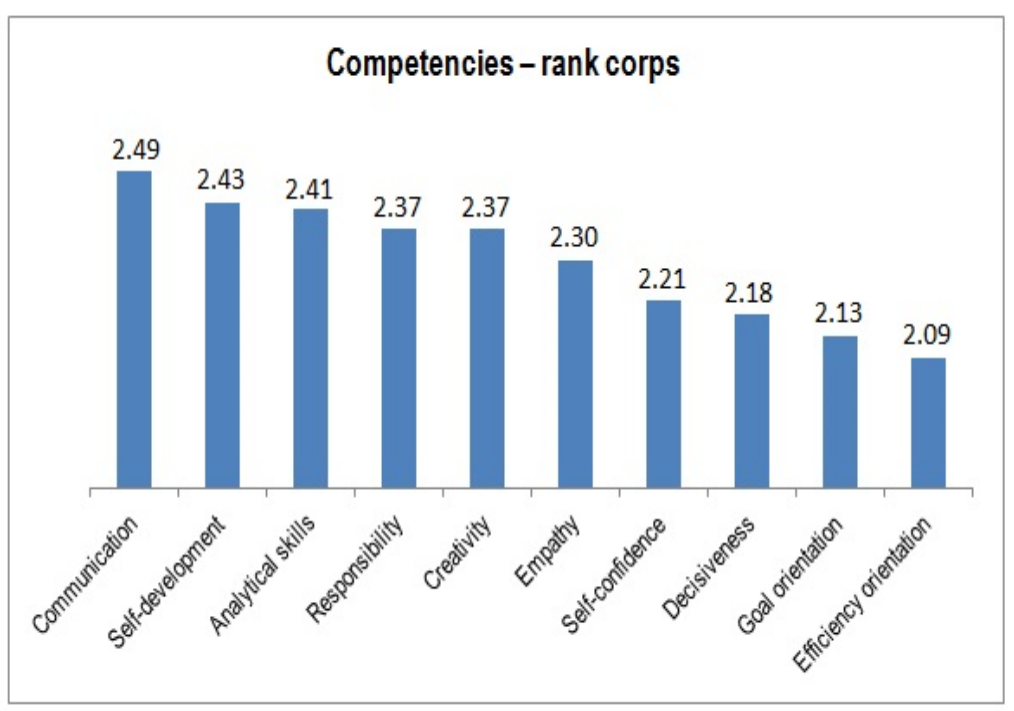

Graph 1: Overall summary competence evaluation by all groups interviewed

Tab. 1: Assessing managerial competencies by individual groups of respondents

\begin{tabular}{|l|c|c|c|}
\hline Competence & GSC & SOC & BOC \\
\hline Communication & 2.52 & 2.49 & 2.47 \\
\hline Self-development & 2.43 & 2.48 & 2.37 \\
\hline Analytical skills & 2.39 & 2.37 & 2.47 \\
\hline Responsibility & 2.39 & 2.39 & 2.32 \\
\hline Creativity & 2.44 & 2.35 & 2.31 \\
\hline Empathy & 2.62 & 2.33 & 1.95 \\
\hline Self-confidence & 2.28 & 2.24 & 2.11 \\
\hline Decisiveness & 2.36 & 2.05 & 2.13 \\
\hline Goal orientation & 2.13 & 2.16 & 2.11 \\
\hline Efficiency orientation & 1.99 & 2.21 & 2.06 \\
\hline
\end{tabular}

Tab. 2: Ten top assessed skills within individual competencies

\begin{tabular}{|c|l|c|l|}
\hline Order & 10 top assessed skills - GSC, SOC, BOC & Average & Competence \\
\hline 1 & Presence of plan required & 1.73 & Goal orientation \\
\hline 2 & Providing support and assistance to subordinates & 1.85 & Efficiency orientation \\
\hline 3 & Applying personal strengths & 1.91 & Self-confidence \\
\hline 4 & Maintaining dignity of subordinates & 1.96 & Empathy \\
\hline 5 & Readiness to change the situation & 1.97 & Goal orientation \\
\hline 6 & Independence of decision-making & 1.99 & Efficiency orientation \\
\hline 7 & Putting orders, plans and regulations into practice & 2.03 & Efficiency orientation \\
\hline 8 & Learning from wrong decisions & 2.06 & Decisiveness \\
\hline 9 & Responsibility for the whole, formation & 2.09 & Responsibility \\
\hline 10 & Gradual steps towards achieving objectives & 2.11 & Goal orientation \\
\hline
\end{tabular}


Tab. 3: Ten worst assessed skills within individual competencies

\begin{tabular}{|c|l|c|l|}
\hline Order & 10 worst assessed skills - GSC, SOC, BOC & Average & Competence \\
\hline 1 & Communication in a foreign language & 3.13 & Communication \\
\hline 2 & Mistakes of subordinates are our own mistakes as well & 2.73 & Responsibility \\
\hline 3 & Obstacles and failures cannot thwart to achieve objectives & 2.72 & Goal orientation \\
\hline 4 & Non-standard methods of solution & 2.66 & Creativity \\
\hline 5 & Self-studying documents, books and regulations & 2.61 & Self-development \\
\hline 6 & Concise, clear and understandable expression & 2.54 & Communication \\
\hline 7 & $\begin{array}{l}\text { Assessing and anticipating consequences of our own } \\
\text { decision }\end{array}$ & 2.51 & Analytical skills \\
\hline 8 & To emphasize with the situation of subordinates & 2.48 & Empathy \\
\hline 9 & Voluntary participation in training and courses at schools & 2.48 & Self-development \\
\hline 10 & Supporting subordinates at the right time & 2.47 & Empathy \\
\hline
\end{tabular}

\section{Communication}

Ability to be listened to and accepted by others, to grasp substantial and build relationships among others should become basic tasks of a commander. In our opinion, developing the commander's competence communication should be focused predominantly on active listening skills, assertive behaviour, ability to prevent and resolve conflicts, communicating concise, accurate and unambiguous information covering also feedback to verify the degree of understanding the information sent as well as language proficiency including cultural differences acquaintance, which is particularly important whether the operation abroad is successful or not.

\section{Self-development}

Developing this competence is based on the cognition of our own personality, developing our strengths and reducing weaknesses. We assume that unless commanders are willing to work on themselves and study, they are not able to develop their subordinates, and the military organization will be at a standstill. A commander acting as an example for others is for his subordinates an example to be followed: and only if he is working on himself continually, is willing to learn, and responds to relevant changes. Appropriately applied feedback belongs to efficient tools used for the purpose of commanders' development, e.g., career development evaluation interviews, assessment of training and commanders' preparation. The feedback is efficient particularly in cases when practised by an experienced commander who acts as a consultant (mentor, coach). A commander should also be concerned about the training courses level of his subordinates, follow, what knowledge, skills and habits were acquired and whether are used by soldiers in practice.

\section{Analytical thinking}

The analytical thinking is characterized as an ability to look at the problem and consider it from several points of view and then select the best solution from all solutions offered; this procedure presents problems even for some experienced commanders. In our opinion, such a competence should be developed purposefully, particularly in the tactical preparation, which enables creating model situations resembling real life ones. This can be achieved by applying simulation technologies, which allows recording the entire decision-making process and offer the objective feedback as well.

\section{Conclusion}

The paper offered ten detailed definitions of commanders' key competences, i.e., decisiveness, responsibility, goal orientation, efficiency orientation, selfdevelopment, analytical thinking, empathy, self-confidence, communication, creativity, 
and indicators were created to measure them. Resulting from these indicators, a questionnaire was developed, data collected from three groups of respondents, i.e., participants of the General Staff course, course for senior officer and basic officers' course graduates (officers in commander and staff functions at $7^{\text {th }}$ mechanized brigade), which are engaged in strategic, organizational and direct leadership. The research outcomes showed that the development of commander's competence should be focused particularly on competencies covering communication, self-development, and analytical thinking ability. The last part outlines methods how these competencies can be developed among commanders. In further research, the authors are going to focus on developing methods for individual competencies, both in accredited study programs for future commanders at the University of Defence and in career courses and commanders' preparation with troops.

\section{References}

[1] VRCHOTA, J. Vymezení klíčových manažerských kompetencí pro řizení podniků v ČR. České Budějovice: Jihočeská univerzita, Ekonomická fakulta, 2012. 149 s. Disertační práce.

[2] BAUER, S. High Potentials Study. CONTACT e. V. [online]. Lecture presented at University Kaiserslautern May 7, 2003. [quoted 10-10-2016]. Available from http://www.unikl.de/CONTACT/docs/presentation_uni_kl_20030507.pdf

[3] The U. S. Army Leadership Field Manual. McGraw-Hill: 2004. ISBN 978-0-07-143699-1.

[4] Národní soustava povolání. [online]. [cit. 10-10-2016] Available from: http://kompetence.nsp.cz/mekkeKompetence.aspx

[5] Vyhláška o postupu při služebních hodnocení vojáki̊ a jeho hlediscích. Vyhláška č. $189 / 2015 \mathrm{Sb}$.

[6] VRCHOTA, J. Manažerské kompetence studentů EF. In: INPROFORUM 2009: Sborník z mezinárodní konference „Global Economic Crisis - Challenge for the Regions". České Budějovice: Ekonomická fakulta, 5.- 6. listopad 2009, s. 421-425. ISBN 978-80-7394-173-4.

[7] NOVÁK, P. Manažerské kompetence v malých podnicích. Brno: Vysoké učení technické v Brně, Fakulta podnikatelská, 2012, 157 s. Disertační práce. 